\title{
OXYTOCIN DOSE ANALYSIS OF BREASTMILK PRODUCTION THROUGH INDUCTION LABOR
}

\author{
Sara Nurmala ${ }^{\left.a^{*}\right)}$, Cantika Zaddana ${ }^{a}$ \\ ${ }^{a)}$ Universitas Pakuan, Bogor, Indonesia \\ ${ }^{*}$ Corresponding Author : sara.nurmala@gmail.com
}

\begin{abstract}
Abstrak. Breast milk is the only first food that can be consumed by newborns until the age reaches six months. therefore it is very important to know by the mother who is pregnant and will give birth about the importance of breast milk. Oxytocin drugs have similar functions to the natural hormone oxytocin produced by the body. This drug serves to trigger or strengthen the contraction of the uterine muscle. Therefore, oxytocin can be used to stimulate (induce) labor and stop bleeding after childbirth. In addition, this drug can also help stimulate the release of breast milk in breastfeeding mothers. Oxytocin should be avoided by pregnant women who can not give birth normally, for example because it has a narrow pelvis, suffering from placenta previa, or having a too strong uterine contractions. Oxytocin is also prohibited for pregnant women with cephalopelvic disproportion, impaired fetal conditions, uterine damage, or a history of caesarean section. In this study we see whether there is effect of different doses of oxytocin on the quantity of breastmilk produced. oxytocin doses were administered with 3 doses of 5 UI, 10 UI and 15 UI. the dose of oxytocin is administered once per incidence of labor. maternal results obtained by oxytocin induction of $5 \mathrm{UI}$ and $10 \mathrm{UI}$ obtained breastmilk averaging $10 \mathrm{ml}$ in the first 24 hours after delivery. and a mother with oxytocin induction 15 UI received an average breastmilk of $10 \mathrm{ml}$ at 24 hours after delivery.
\end{abstract}

Keywords: oxytocin; breast milk; induction; hormones; labor

\section{INTRODUCTION}

Labor is the process of opening and thinning of the cervix, and where the fetus and membranes descend into the birth canal and are pushed out through the birth canal (Revinel [1])

Labor and normal delivery is a process of fetal expulsion occurring in a month-long pregnancy (37-42 weeks) spontaneously born with a rear-end presentation that lasts in an uncomplicated 18 hours in both the mother and the fetus. Ahead of labor there is a decrease in the hormone progesterone (Ira [2]). This hormone serves to prepare the condition of the uterus to be inhabited by fetal candidates. In early pregnancy, progesterone is needed to avoid miscarriage. However, before the delivery of women the function is no longer needed so that production decreases. Together with other hormones estrogen increases before delivery. This hormone works to stimulate the mammary gland and cause uterine contractions (Subur [3]). This hormone is produced by the placenta during the pregnancy process until the time of delivery.

Many oxytocin hormones are produced before delivery. Oxytosis causes contractions of the uterine smooth muscles that serve to decrease the baby's head. On the other hand, the hormone oxytocin is responsible for preparing lactation by opening the breast milk channels from the alveolus to the nipple (Roesli [4]). Oxytocin production increases when nipple stimulation is performed. This method is done when the contraction of the maternal uterus is inadekuat. in normal labor is sometimes preceded by oxytocin induction, the goal is to help speed up the opening of the cervix so that the baby can be born. Induction of Childbirth is an action to stimulate uterine contractions for labor. In labor induction is usually used oxytocin, a hormone that causes uterine contractions become stronger (Anne [5]).

Factors that prevent a mother's obstacles can not breastfeed babies include hormonal factors, maternal psychological factors, infant physiology factors and maternal physiological factors (Prasetyono [6]). Psychological factors that stress the mother will inhibit the formation of oxytocin. Family support is very important for breastfeeding mothers to avoid stress, sadness and fatigue during breastfeeding (Meiyana [7]). Factors that prevent a mother's obstacles can not breastfeed babies include hormonal factors, maternal psychological factors, infant physiology factors and maternal physiological factors. Psychological factors that stress the mother will inhibit the formation of oxytocin. Family support is very important for breastfeeding mothers to avoid stress, sadness and fatigue during breastfeeding (IDAI [8] )

Maternal mothers with oxytocin induction exhibit similar positive personality traits during breastfeeding such as anxiety reduction, depressed feelings and increased social and maternal feelings that have previously been thought to originate only from endogenous oxytocin. (Barbara [9])

A randomized double-blind study was conducted on the mother who gave birth and the result of the use of nasal spray oxytocin did not significantly affect the total volume of breast milk produced, since most mothers considered the nasal spray obtained contained oxytocin although in fact only placebo (Fewtrell [10]). 


\section{RESEARCH METHODS}

This study was designed as cross-sectional study. The research was conducted in Banten province public hospital, Indonesia which was in Januari to March 2017. This study was followed by 90 mothers who gave birth normally with oxytocin induction, consisting of 30 oxitosin-induced women with a dose of 5 UI, 30 oxytocin induced mothers with 10 UI doses and 30 oxitosin-induced mothers with a dose of 15 UI. After the mother gives birth to observations on the production of breast milk mother by pumping every 3-6 hours once during the first 24 hours after delivery.

Administration of oxytocin in the mother giving birth is done through intravenous drip. administration of oxytocin by drip is the safest way of administration because the dosage and rate of oxytocin administration can be adjusted compared to intravenous injection (Made [11]).

In the first 24 hours the mothers who followed this study were given the same food and the same nutrition, and continued to breastfeed directly to their infants. Data were analyzed using the SPSS for windows (version 17.0). The correlation between variables were analyzed with Spearmans.

\section{RESULTS AND DISCUSSION}

The results of this study found breast milk mother who gave birth to normal with oxytocin induction dose 5 UI are $5 \mathrm{ml}$ breast milk as many as 8 people, $10 \mathrm{ml}$ as many as 14 people, and $15 \mathrm{ml}$ as many as 8 people. the average breast milk of a total of 30 mothers who gave birth normally with oxytocin induction with a dose of 5 UI was $10 \mathrm{ml}$.

The mother who gave birth to normal with oxytocin induction dose $10 \mathrm{UI}$ are $5 \mathrm{ml}$ breast milk as much as 4 people, $10 \mathrm{ml}$ as many as 22 people, and $15 \mathrm{ml}$ as many as 4 people. the average breast milk of a total of 30 mothers who gave birth normally with oxytocin induction with a dose of 10 UI was $10 \mathrm{ml}$.

The mother who gave birth to normal with oxytocin induction dosage $15 \mathrm{UI}$ is $10 \mathrm{ml}$ breast milk as much as 4 people, $15 \mathrm{ml}$ as many as 2 people, $20 \mathrm{ml}$ as many as 7 people, $25 \mathrm{ml}$ as many as 12 people, and $30 \mathrm{ml}$ as many as 5 people. the average breast milk of a total of 30 mothers who gave birth normally with oxytocin induction at a dose of 15 UI was $22 \mathrm{ml}$.

\section{CONCLUSION}

The results showed that the majority of mothers who gave birth with a dose of oxytocin induction of 5 UI and 10 UI were mothers with an average $10 \mathrm{ml}$ breastmilk results, taken 24 hours after maternal mothers. Then for mothers who gave birth to a dose of oxytocin induction 15 UI was a mother with flat results of breastmilk $22 \mathrm{ml}$, here it is seen that the greater dose ocytosin used, the greater the results obtained breastmilk. mothers who did this research before did not understand about the importance of breast milk to the baby. Spearman correlation test showed that the magnitude of oxyphine dose was positively related to the quantity of breast milk produced within the first 24 hours after delivery. because the first 24 hours baby is a key of success in breastfeeding. If not stimulated it will be difficult to release breast milk. It is important to provide training for new moments of birth to improve your mother's knowledge, so the mother is ready to breastfeed her baby.

Further research is needed with more samples and measurements of oxytocin levels in the blood so that the results of the study are more scientific and can be generalized. This research also needs to be done at private hospitals to know the differences in the choice of delivery methods and their correlation with the success of reflex ejection of breast milk.

\section{REFERENSI}

[1] Revinel. 2014. Perbandingan Efektifitas Persalinan Aktif Kala III Antara Pemberian Misoprostol PerRektal dan Oksitosin Intramuskuler. pustaka.unpad.ac.id

[2] Ira KG. 2005. The Oxytocin Factor: Tapping The Hormone Of Calm, Love And Healing. Journal Of Midwifery \& Women's Health. 50(1): e6.

[3] Subur W, Dian A, Merry T. 2012. Hubungan Pendidikan dan Pengetahuan Ibu tentang ASI Eksklusif dengan Sikap terhadap Pemberian ASI Eksklusif. Jurnal Kedokteran Muhammadiyah. 1(1): 25-29.

[4] Roesli U. 2008. Inisiasi Menyusu Dini Plus ASI Eksklusif. Jakarta: Pustaka Bunda.

[5] Anne VA. Hallgren, H. Hogberg, I. Hurtig, V. Odlind. 2002. Plasma Oxytocin Level In Women During Labor With Or Without Epidural Analgesia. Acta Obstetricia et Gynecologica Scandinavica. 11(81): 1033-1039.

[6] Prasetyono DS. 2009. Buku Pintar ASI Eksklusif. Yogyakarta: Diva Press.

[7] Meiyana DR. 2010. Faktor-Faktor Yang Mempengaruhi Pemberian Asi Eksklusif Pada Ibu Menyusui Di Kelurahan Pedalangan Kecamatan Banyumanik Kota Semarang. Fakultas Kedokteran Universitas Diponegoro. Jurnal Kesmadaska. 1(1):817.

[8] Ikatan Dokter Anak Indonesia. 2010. Indonesia Menyusui. Jakarta: Badan Penerbit IDAI.

[9] Barbara F, Claudia CD, Sonia B, Catarina C. 2013. Breastfeeding and Postpartum Depression : State of the Art Review. Jornal de Pediatria. 89(4): 332-338.

[10] Fewtrell M. S, K. L. Loh, A. Blake, D. A. Ridout, J. Hawdon. 2006. Randomised Double Blind Trial Of Oxytocin Nasal Spray In Mother Expressing Breast Milk For Preterm Infants. Arch Dis Child Fetal Neonatal. 91(3): F169-F174.

[11] Made AK, Made W, I Nyoman HS, I Made GW. 2013. Perbandingan Efek Oksitosin 3UI, 5UI dan 
10UI Terhadap Kontraksi Uterus dan Respon Kardiovaskular pada Seksio Saesarea dengan Anestesi Blok Subarakhnoid. Jurnal Medicina. 3(44): 143-149. 